\title{
MASJID AL-IKHLAS SEBAGAI PUSAT BUDAYA KEAGAMAAN ISLAM MASYARAKAT TEMPEL, CATURTUNGGAL, DEPOK, SLEMAN, YOGYAKARTA
}

\author{
Miftahul Khoiri* \\ Program Studi Magister Sejarah Peradaban Islam, Fakultas Adab dan IImu Budaya, UIN Sunan Kalijaga, Yogyakarta, \\ Indonesia
}

\begin{abstract}
In this article, it aims to describe the history of the AlIkhlas mosque, the religious cultures in the Al-Ikhlas mosque run by the Tempel community, Caturtunggal, Depok, Sleman, DIY, and also analyze the establishment of the Al-Ikhlas mosque. With a qualitative, descriptive, analytical approach as field research, this paper concludes that the mosque of Al-Ikhlas was established on September 6, $1988 A D$, at the wishes of the community, religious leaders. And there are a number of religious cultures in Al-Ikhlas Mosque, namely: Islamic cultural arts, including the reading art of Al-Qur'an or TPQ (Al-Qur'an Education Park). Art of Hadroh or Banjari training. Majelis Ta'lim includes, Thursday Wage Recitation, Amanah Recitation and Polyclinic. As for the reason for its establishment, because the community did not have a place of worship at that time, so a mosque had to be built for worship and other activities.
\end{abstract}

Keywords: mosque, Islamic Cultural Center, Tempel.

\section{Abstrak}

Dalam artikel ini, bertujuan untuk mendeskripsikan sejarah masjid Al-lkhlas, budaya-budaya keagamaan yang ada di masjid Al-lkhlas yang di jalankan oleh masyarakat Tempel, Caturtunggal, Depok, Sleman, DIY, dan juga menganalisis pendirian dari masjid Al-Ikhlas. Dengan pendekatan kualitatif, deskriptif, analitis sebagai penelitian lapangan, tulisan ini menyimpulkan bahwa masjid Al-Ikhlas berdiri tahun 06 September 1988 M, atas keinginan masyarakat, tokoh agama. Dan ada beberapa budaya keagamaan di masjid Al-Ikhlas ini, yaitu: Seni budaya Islam, meliputi Seni pembelajaran baca Al-Qur'an atau TPQ (Taman Pendidikan Al-Qur'an). Seni pelatihan Hadroh atau Banjari. Majelis Ta'lim meliputi, Pengajian Kamis Wage, Pengajian Amanah, dan Poliklinik. Sedangkan alasan pendiriannya, karena masyarakat memang tidak memiliki tempat ibadah pada saat itu, sehingga harus dibangun sebuah masjid untuk ibadah dan aktivitas yang lainnya.

Kata Kunci: masjid, pusat kebudayaan Islam, Tempel.

\section{PENDAHULUAN}

Masjid pada umumnya dipahami oleh masyarakat sebagai tempat ibadah saja, seperti shalat, padahal fungsi masjid lebih luas dari itu. Fungsi masjid dijadikan simbol persatuan umat dan masjid sebagai pusat peribadatan dan peradaban. Sekolah-sekolah dan universitas-universitas dahulu bermunculan justru dari masjid. Masjid Al-Azhar di Mesir merupakan salah satu contoh yang dapat dikenal oleh umat Islam di Indonesia maupun dunia. Masjid ini mampu memberikan beasiswa bagi para pelajar dan mahasiswa, bahkan pengentasan kemiskinan merupakan program nyata masjid.

Dikatakan kebudayaan tentu hal itu mempunyai seni, ekspresi seni dimunculkan dalam masjid, khususnya dalam seni arsitektur sebenarnya tidak terlepas dari ekspresi manusia itu sendiri yang merupakan makhluk dengan fitrah seni cinta pada keindahan. Seni adalah semua yang menimbulkan keindahan. Bahkan Shihab mengatakan seni merupakan ekspresi ruh dan budaya manusia yang mengandung dan mengungkapkan keindahan (Rifa'i, 2005, p. 69).

Seperti halnya masjid Al-Ikhlas. Masjid Al-Ikhlas merupakan masjid yang ada di Padukuhan Tempel, Kelurahan, Caturtungal, Depok, Sleman, DIY, yang memiliki salah

\footnotetext{
*Correspondance Author: techochoir@gmail.com

Article History | Submitted: December 5, 2019 | Accepted: January 16, 2020 | Published: January 16, 2020

How to Cite (APA $6^{\text {th }}$ Edition style):

Khoiri, M. (2020). Masjid Al-Ikhlas sebagai Pusat Budaya Keagamaan Islam Masyarakat Tempel, Caturtunggal, 
satu peran dalam menjalankan budaya keagamaan bagi masyarakat tempel. Di masjid Al-Ikhlas ini tidak hanya dibuat sebagai tempat ibadah jamaah shalat lima waktu saja. Tetapi juga banyak aktivitas-aktivitas yang lainnya, seperti aktivitas budaya keagamaan Islam, yang meliputi pengajian kamis wage, maupun pengajian amanah, pembacaan sholawat Barzanji dan Hadroh, pengajaran Al-Qur'an bagi anak-anak maupun orang dewasa dan orang tua, dan ada juga poliklinik. Untuk lebih memperjelas dan mefokuskan dalam pembahasan artikel ini, maka dibuatlah rumusan masalah sebagai berikut: Bagaimana sejarah berdirinya masjid Al-Ikhlas? Apa saja budaya keagamaan masyarakat tempel di masjid Al-Ikhlas? Mengapa masjid Al-Ikhlas didirikan? Di samping itu. Tujuan dari penelitian ini, yang tak lain adalah untuk mengetahui sejarah dari berdirinya Masjid Al-Ikhlas tersebut. Juga untuk mengetahui aktivitas dan kegiatan yang terjadi di Masjid Al-Ikhlas. Dan yang tak ketinggalan yaitu menganalisis terjadinya pembangunan dari Masjid Al-Ikhlas tersebut.

\section{METODE DAN FOKUS PENELITIAN}

Penelitian ini merupakan penelitian sejarah dan budaya. Yang mana Dalam metode penelitian sejarah, Kuntowijoyo membaginya ke dalam lima tahapan. Kelima tahapan tersebut yaitu: pertama pemilihan topik, yang mana pada tahap ini penulis memilih topik Masjid Al-Ikhlas sebagai pusat budaya Islam. Kedua pengumpulan sumber (heuristik), dalam tahap ini penulis melakukan wawancara dan observasi terhadap pengurus Masjid dan masyarakat sekitar. Ketiga verifikasi (kritik sejarah, keabsahan sumber). Keempat interpretasi (analisis dan sintesis, dan yang kelima atau terakhir adalah penulisan atau historiografi (Kuntowijoyo, 1995, p. 89). Adapun yang menjadi objek kajian dan konteknya adalah Masjid Al-Ikhlas dan Masyarakat Padukuhan Tempel, Caturtunggal, Depok, Sleman, Daerah Istimewa Yogyakarta (DIY).

Sebuah penelitian akan berguna ketika akan menggunakan pendekatan yang tepat. Sartono Kartodirjo mengungkapkan bahwa penggambaran seorang penulis mengenai suatu peristiwa sangat tergantung pada pendekatan, dari segi mana penulis memandangnya, dimensi mana yang diperhatikan, unsur-unsur mana yang diungkapkan dan lain sebagainnya. Menurut Sartono, pelukisan sebuah peristiwa sangat ditentukan oleh pendekatan yang dipakai (Kartodirdjo, 2016, p. 4)

Penulisan ini merupakan penelitian sejarah dan budaya. Yang mana dalam mendiskripsikan dan menganalisisnya, penulis menggunakan pendekatan sosiologi dan antropologi. Pendekatan sosiologi diperlukan untuk melihat interaksi antara masyarakat, pola prilaku masyarakat juga struktur masyarakat dan juga kondisi budaya masyarakat. Sedangkan pendekatan antropologi diperlukan untuk melihat budayabudaya masyarakat yang ada pada saat kegiatan-kegiatan keagamaan yang di Masjid AlIkhlas. Uraian metode penelitian yang digunakan serta fokus kajian (objek kajian dan konteks) dalam artikel penelitian anda.

\section{HASIL DAN PEMBAHASAN}

\section{Sejarah Berdirinya Masjid Al-Ikhlas}

Masjid Al-Ikhlas berada di padukuan Tempel, Caturtunggal, Depok, Sleman, DIY. Berdirinya Masjid Al-Ikhlas ini dipelopori oleh para tokoh-tokoh agama di 
Masyarakat Tempel yang pada saat itu memang membutuhkan tempat untuk beribadah (sholat). Para tokoh tersebut adalah bapak Supriyadi, Panjang Sularso, Sukirman. Tiga tokoh tersebut yang mempelopori berdirinya masjid Al-Ikhlas. Masjid Al-Ikhlas berdiri pada tanggal o6 September $1988 \mathrm{M}$, yang memang kondisinya pada saat itu padukuhan Tempel tidak memiliki Masjid, dan jika melakukan ibadah sholat, masyarakatnya masih menjalankan sholat di tempat Padukuhan (pendopo).

Awalnya tempat ibadah ini bukan bernama Masjid, tetapi namanya Langgar (mushollah). Pada waktu itu hanya sebagian masyarakat yang beribadah sholat di langgar tersebut, karena memang masyarakatnya yang tergolong masih Islam Abangan, sehingga mereka jarang datang ke Langgar tersebut. pada awal berdirinya masjid tersebut, dalam hal kepengurusan belum terlalu diperhatikan atau belum terbentuk kepengurusannya. Dan sampai tahun 1995 barulah kepengurusan tersebut dibentuk, karena ditahun 1995 tersebut, langgar itu bertranformasi menjadi Masjid, sehingga mengharuskan para masyarakat untuk membuat struktur kepengurusan Masjid.

Dalam awal berdirinya, semenjak masih bernama Langgar, tempat ibadah ini sudah ada aktivitasnya selain dibuat sholat, yaitu aktivitas mengaji yang dilakukan oleh para tokoh-tokoh pelopor tersebut, dan sebagian masyarakat yang sudah mau ke masjid. Setelah dibentuk kepengurusan, yang mana kepengurusan pertama diketuai oleh Sukirman, tokoh yang sangat besar jasanya dalam pendirian Masjid tersebut, dan berakhir dalam masa kepemimpinannya sebagai takmir tahun 1998.

Kemudian, Setelah itu ketua kepengurusan dilanjutkan oleh Panjang Sularso, tahun 1998 sampai 2002, yang mana Panjang Sularso tersebut juga salah satu pelopor dari pembangunan masjid Al-Ikhlas. Dalam masa tersebut, aktivitas bertambah dengan adanya pengajian para kaum ibu-ibu, yang dinamakan dengan pengajian amanah. Setelah masa kepengurusan Panjang Sularso telah habis, kemudian diteruskan oleh pak budi, yang menjabat tahun 2002 sampai 2006, dalam masa ini, aktivitas yang ada di masjid berjalan seperti biasa selama kurang lebih empat tahun dan tidak ada tambahan aktivitas apapun.

Setelah itu kepemimpinan dipegang oleh Enrizal yang menjabat tahun 2007 sampai 2010, di mana masa kepengurusan ini aktivitas bertambah dengan adanya pengajian untuk anak-anak yang ditampung dalam lembaga TPQ (Taman Pendidikan Qur'an), selain itu aktivitas yang sudah ada dulu juga semakin aktif. Kemudia kepengurusan selanjutnya dipegang lagi oleh Sukirman tahun 2011 sampai 2014 yang dulunya sudah pernah menjabat yang pertama. Dalam kepemimpinannya yang kedua ini, aktivitas baru mulai digalakkan seperti yang dulunya hanya pengajian ibu-ibu, anakanak yang tertampung dalam lembaga TPQ, dalam kepengurusan kali ini ada tambahan pengajian yang diikuti oleh kaum bapak-bapak dan ibu-ibu, yang dilaksanakan satu bulan sekali dengan mengundang penceramah dari luar.

Selanjutnya kepengurusan dipegang oleh Pak Zaenal dari mulai tahun 2015 sampai sekarang. dalam masa ini, setelah dulunya ada banyak berbagai macam aktivitas keagamaan, dalam masa ini didirikan piliklinik, yang mana poliklinik ini dibuat untuk melayani masyarakat untuk berobat. Dan dibuka pelayanannya setiap satu minggu sekali, tepat hari senin. ${ }^{1}$ 


\section{Budaya dan Keagamaan Masyarakat Tempel}

Masyarakat Tempel mayoritas beragama Islam, dan ada dua ormas keagamaan yang berada di masyarakat. Walaupun ada dua ormas keagamaan, tetapi mereka tetap hidup rukun saling bergandengan, menjalankan ibadah dan aktivitas keagamaan di Masjid Al-Ikhlas secara bersama-sama, tanpa ada rasa permusuhan. Diantara aktivitas budaya keagamaan masyarakat Tempel di masjid Al-Ikhlas adalah sebagai berikut:

Seni budaya Islam

Seni adalah penjelmaan rasa indah yang terkandung dalam jiwa manusia, yang dilahirkan dengan perantaraan alat komunikasi ke dalam bentuk yang dapat ditangkap oleh indera pendengar, indera penglihat, atau dilahirkan dengan perantaraan gerak. Sudah menjadi fitrah, bahwa manusia menyukai keindahan. Seseorang akan senang ketika melihat hamparan sawah yang menghijau dengan panorama khas pedesaan. Mengapa demikian, karena itu merupakan bentuk keindahan.

Salah satu mukjizat Al-Qur'an, misalnya, adalah bahasanya yang sangat indah, sehingga Abdul Walid, sastrawan terbaik Arab yang diutus pemimpin Quraisy untuk menantang keindahan Al-Qur'an, langsung mengakui keindahan Al-Qur'an tak tertandingi. Dalam membaca Al-Qur'an pun kita dituntut untuk menggabungkan keindahan suara dengan ketepatan bacaan tajwidnya. Rasulullah SAW bersabda: "Hiasilah Al-Qur'an dengan suaramu". "Innallaha Jamil Wa Yuhibbul Jamal" (Sesungguhnya Allah itu indah dan menyukai keindahan), kata Rasulullah SAW, Manusia menyukai keindahan karena efek dari keindahan Allah SWT. Al Jamiil (Yang Maha Indah) pun merupakan salah satu dari nama-nama Allah SWT. Islam menyeru umatnya untuk bisa merasakan, menikmati serta mentadaburi keindahan. Maka dari itu tidak ada larangan bagi umat islam untuk mengekspresikan keindahan yang ada dalam benak mereka. Dalam hal ini tentunya Islam sebagai suatu agama yang syamil memberikan panduan agar kreativitas yang dihasilkan umatnya bermanfaat bagi diri mereka sendiri dan umat manusia. Tidak dibiarkan sembarangan tanpa arah yang akhirnya menimbulkan mudharat. Hal inilah yang mendasari pentingnya memberikan pembinaan seni dan budaya para jama'ah masjid, untuk memenuhi kebutuhan para jama'ah masjid akan hal tersebut. Pembinaan seni dan budaya ini mempunyai nilai penting terutama mengingat Islam sebagai agama, dalam sejarahnya juga berkembang, melalui sarana seni dan budaya ini (Kurniawan, 2014, p. 181).

Seni pembelajaran baca Al-Qur'an atau TPQ (Taman Pendidikan Al-Qur'an)

Masjid bisa diperlengkapi dengan seni belajar baca Al-Qur'an atau taman pendidikan Al-Qur'an (TPQ), di mana lembaga ini biasanya dikunjungi oleh anak-anak di bawah sepuluh tahun. Di daerah perkotaan pada umumnya mendirikan taman pendidikan Al-Qur'an, di daerah pedesaan pengajian Al-Qur'an anak-anak biasanya diselenggarakan setelah shalat maghrib yang dibimbing oleh seorang kyai. ${ }^{2}$

Begitu juga di masjid Al-Ikhlas. Di masjid Al-Ikhlas, pembelajaran seni baca AlQur'an ataupun TPQ, disamping diikuti oleh anak-anak, ada juga orang-orang tua yang 
juga mengadakan pembelajaran Al-Qur'an tersebut. pembinaan atau pembelajaran seni budaya Islam sudah ada sebelas tahun yang lalu, mulai dua ribu delapan dan berjalan sampai sekarang, yaitu pembelajaran seni baca Al-Qur'an. Di mana pembelajaran seni baca Al-Qur'an ini diikuti oleh semua kalangan, mulai dari anak-anak yang terhimpun dalam lembaga TPQ (Taman Pendidikan Al-Qur'an), yang diasuh oleh para marbot dari masjid Al-Ikhlas sendiri, yang waktu pengajarannya setelah sholat Ashar. Dalam jenjang anak-anak yang terhimpun dalam TPQ tersebut, diikuti sekitar 50 anak-anak dari masyarakat Tempel. Kemudian orang dewasa dan orang tua, di mana proses pembelajaran seni baca Al-Qur'an untuk orang dewasa dan orang ini, dilaksanakan satu minggu sekali setiap malam Kamis setelah Isya', dan diikuti sekitar 25-an orang yang terdiri dari kaum laki-laki dan kaum perempuan. yang mana dalam pembelajaran seni baca Al-Qur'an ini juga ada seorang ustadz sebagai pengajarnya.

Seni pelatihan Hadroh atau Banjari

Selain pembelajaran seni baca Al-Qur'an. Ada juga pembelajaran seni budaya Islam lainnya, yaitu pembelajaran seni Hadroh atau banjarian. Hadroh atau Banjari yang pada umumnya dimainkan oleh kaum laki-laki, tetapi dalam pembelajaran seni Hadroh atau banjari di masjid Al-Ikhlas ini dimainkan oleh kaum hawa, yakni para ibu-ibu. Seni Hadroh terdiri dari lima belas orang, yang dimainkan oleh para ibu-ibu masyarakat Tempel. Dua belas orang sebagai pemegang dan memainkan rebana. sedangkan tiga orang lainnya sebagai vokalis, yang bertugas untuk menyanyikan sebuah lagu Islami.

Seni pelatihan Hadroh ini dilakukan setiap satu minggu sekali, yaitu setiap malam sabtu. Dalam pelatihan Hadroh ini, para ibu-ibu tidak sembarang latihan, karena pada pelatihan ini telah mengundang pelatih dari luar, yang disuruh untuk melatih Hadroh tersebut.

Dalam pelatihan Hadroh atau ketika acara di masjid, biasanya lagu-lagu yang dinyanyikan cukup bervariasi, seperti halnya ada sholawat-sholawat yang ada di buku Dziba', dan ada pula syair-syair Jawa yang disenandungkan. ${ }^{3}$

Majelis Ta'lim

Pada umumnya, masjid memiliki majelis ta'lim yang menyelenggarakan pengajian pada hari-hari tertentu. Ada yang menyelenggarakan pada setiap hari Sabtu. Ada yang melakukannya setiap hari Rabu yang kemudian dikenal sebagai majelis Reboan. Ada juga yang memilih waktu malam, misalnya setiap hari Kamis malam Jum'at.

Penyelenggaraan pengajian oleh majelis ta'lim merupakan upaya untuk memakmurkan masjid. Pengajian yang diselenggarakan oleh majelis ta'lim memiliki dampak lainnya, seperti adanya ikatan atau kelompok-kelompok arisan atau kelompokkelompok ekonomi lainnya. Dengan terselenggaranya pengajian, maka banyak orang membuka kios, sehingga pengajian memiliki dampak ekonomi lainnya.4

Dalam hal ini, masjid Al-Ikhlas mempunyai beberapa majelis ta'lim yang diikuti oleh bapak-bapak, maupun ibu-ibu yang berada di lingkungan masyarakat Tempel. Majelis ta'lim yang diselenggarakan di masjid Al-Ikhlas diantaranya adalah: 
Pengajian Kamis Wage

Pengajian Kamis Wage, adalah pengajian yang diikuti oleh para kaum laki-laki dan para kaum ibu-ibu, ada juga anak-anak dan kaum remaja. Pengajian ini mendatangkan penceramah dari luar, yang dirasa mumpuni dalam ilmu keagamaan. Materi yang disampaikan oleh para penceramah dalam pengajian kamis wage ini sangat bermacam-macam. Ada penceramah yang menyampaikan pengajian dalam Kamis Wage ini dengan membahas masalah fiqh, dan ada juga penceramah yang menjelaskan tentang tafsir Al-Qur'an.

Alasan penamaan pengajian ini dengan nama Kamis Wage, karena pengajian ini bertepatan dengan hari Kamis Wage malam Jum'at setiap satu bulan sekali sehingga pengajiannya dinamakan pengajian kamis Wage. Pengajian Kamis Wage ini dimulai setelah sholat Isya' antara jam delapan sampai jam sepuluh. Dimulai dengan bacaan sholawat nabi, dilanjut dengan bacaan surat-surat pendek, dan yang terakhir acara inti yang dibawakan oleh sang penceramah. 5

Pengajian Amanah

Di samping ada pengajian kamis wage yang diikuti oleh para kaum laki-laki dan kaum perempuan. Ada juga pengajian amanah, yang mana pengajian ini hanya diikuti oleh para kaum ibu-ibu. Pengajian ini ada sudah sejak tahuan 2000-an, yang dipelopori oleh Bu Jumirah. Pengajian ini diadakan setiap dua minggu sekali, tepatnya malam Jum'at, dan juga mendatangkan atau mengundang penceramah dari luar. Pengajian amanah ini juga mengundang masyarakat dari luar Tempel, sehingga terlihat meriah dan ramai suasana masjid Al-Ikhlas ketika ada pengajian amanah tersebut. Isi dari acara pengajian amanah tersebut adalah pembacaan kalam illahi (ayat suci), yasin dan tahlil, dan dilanjut dengan mauidhatul hasanah yang disampaikan oleh ustadz atau penceramah yang diundang dari luar tersebut. 6

Poliklinik

Masalah kesehatan umat akan sangat mempengaruhi kualitas iman dan taqwa, termasuk kualitas berfikirnya. Masyarakat yang cerdas pada umumnya dilandasi oleh kesehatan yang prima. Kesehatan dalam arti luas, tidak terbatas pada kesehatan jasmani, tetapi juga kesehatan rohani.

Ajaran agama Islam telah membimbing manusia hidup secara sehat. Ajaran puasa diantaranya adalah untuk menuju kesehatan, baik jasmani maupun rohani. Banyak orang disarankan untuk berpuasa demi kesehatannya. Dan kesehatan jasmani memang sangat tergantung pada kesehatan rohaninya.

Masjid yang pada khususnya dibuat sebagai tempat ibadah, bisa juga berperan dalam rangka membangun kesehatan umat Islam dengan mendirikan poliklinik 7 . Seperti halnya masjid Al-Ikhlas yang ini. Masjid Al-Ikhlas tergolong masjid kecil. Tetapi, walaupun begitu Masjid Al-Ikhlas ini mempunya berbagai macam budaya kegiatan keagamaan ataupun umum. Salah satunya yang tergolong kegiatan umum yang ada di Masjid Al-Ikhlas ini adalah, aktivitas pelayanan kesehatan berupa poliklinik Masjid Al- 
Ikhlas. Poliklinik Masjid Al-Ikhlas ini berdiri tahun 2018, baru satu tahun yang lalu. Berawal dari ide ketua takmir yang mengingginkan adanya pelayanan kesehatan di Masjid Al-Ikhlas tersebut, dengan bekerjasama dengan puskesmas Caturtunggal. Jadwal kegiatan pelayanan kesehatan di poliklinik Masjid Al-Ikhlas, hanya satu minggu sekali, yakni tiap hari senin. Sasaran pelayanan dari poliklinik Masjid Al-Ikhlas ini adalah masyarakat Tempel. Masyarakat Tempel sangat antusias dan senang dalam adanya pelayanan kesehatan gratis yang diadakan oleh Masjid Al-Ikhlas tersebut. menurut ketua takmir Masjid Al-Ikhlas. Diantara tujuan diadakanya pelayanan kesehatan bagi masyarakat Tempel tersebut adalah, agar kesehatan masyarakat bisa terjaga, sehingga jikalau masyarakat sehat, maka diharapkan Masjid Al-Ikhlas yang hanya satu-satunya berada di Tempel ini jika waktunya sholat atau kegiatan yang lain bisa penuh oleh masyarakat-masyarakat Tempel tersebut. 8

Dari pusat kebudayaan di atas tersebut, yang membedakan masjid Al-Ikhlas dengan masjid lainnya yaitu, yang mana masjid yang lain yang berada di sekitar masjid Al-Ikhlas tidak adanya aktivitas poliklinik. Dari sinilah keunikan masjid Al-Ikhlas, karena berbeda dengan masjid-masjid disekitarnya.

Faktor didirikannya Masjid Al-Ikhlas

Masjid dalam sejarahnya mempunyai arti penting dalam kehidupan umat Islam, hal ini karena masjid sejak masa Rasulullah SAW, telah menjadi sentra utama seluruh aktivitas umat Islam generasi awal, bahkan, masjid kala itu menjadi "fasilitas" umat Islam mencapai kemajuan peradaban. Sejarah masjid bermula sesaat setelah Rasulullah SAW, hijrah di Madinah. Langkah pertama yang beliau lakukan di Madinah, adalah mengajak pengikutnya, membangun masjid. Allah SWT ternyata menakdirkan masjid yang dibangun Rasulullah SAW, di Madinah (sebelumnya disebut Yatsrib) menjadi rintisan peradaban umat Islam. Bahkan tempat di mana masjid ini dibangun, benarbenar menjadi Madinah (seperti namanya) yang arti harfiahnya adalah "tempat peradaban" atau paling tidak dari tempat tersebut telah lahir benih-benih peradaban.

Fungsi Masjid dalam sejarah kemunculannya, memang tidak sekedar untuk "tempat sujud" sebagaimana makna harfiahnya, tetapi multifungsi. Pada masa Rasulullah SAW, Masjid berfungsi sebagai sentra kegiatan-kegiatan pendidikan, yakni tempat pembinaan dan pembentukan karakter umat. Bahkan lebih strategis, pada masa Rasulullah SAW, masjid menjadi sentra kegiatan politik, ekonomi, sosial dan budaya umat. Hal ini karena disetiap harinya umat Islam berjumpa dan mendengar arahanarahan Rasulullah SAW tentang hal ini.9

Begitu juga dengan Masjid Al-Ikhlas ini. Menurut Sukirman (tokoh pelopor pembangunan Masjid Al-Ikhlas) dalam sebuah wawancaranya, Tujuan didirikannya Masjid Al-Ikhlas ini, tak lain yaitu sebagai tempat ibadah shalat, baik itu shalat wajib lima waktu maupun shalat sunnah lainnya. Selain sebagai tempat ibadah jamaah shalat wajib maupun shalat sunnah. Masjid Al-Ikhlas juga bertujuan sebagai sarana pendidikan, seperti pengajaran Al-Qur'an yang bernama Taman Pendidikan Al-Qur'an (TPA) bagi anak-anak, dan juga pengajian bagi orang dewasa maupun orang tua.1o

Dalam berkembangnya waktu, yang mana tujuan didirikannya Masjid Al-Ikhlas tersebut hanya sebatas tempat ibadah shalat berjamaah, dan pengajian Al-Qur'an saja. 
Tetapi dengan berjalanya waktu, Masjid Al-Ikhlas ini tidak hanya dibuat untuk shalat, dan pengajaran Al-Qur'an saja, tetapi dengan berjalannya waktu ada banyak aktivitas budaya keagamaan yang ada di masjid Al-Ikhlas tersebut, dan Masjid Al-Ikhlas tersebut menjadi ikon bagi masyarakat Padukahan Tempel.

\section{PENUTUP}

Masjid Al-Ikhlas ini berdiri pada tahun $1988 \mathrm{M}$, atas keinginan para sebagian masyarakat yang juga sebagai pemangku masyarakat. Karena memang pada saat itu masyarakat belum memiliki masjid, dan jika melakukan sholat atau aktivitas kegiatan lainnya menggunakan pendopo. Budaya keagamaan masyarakat Tempel yang ada di masjid AlIkhlas adalah: seni budaya Islam. seni budaya Islam ini ada pelatihan Hadroh, pelatihan baca Al-Qur'an dan secara tartil, baik itu untuk anak-anak maupun orang remaja dan tua. Ada juga pengajian Kamis Wage, pengajian amanah, dan juga poliklinik. Pada awalnya, tujuan didirikanya masjid Al-Ikhlas adalah untuk tempat ibadah shalat jamaah, dan pengajian Al-Qur'an. Tetapi dengan berjalannya waktu, tujuan tersebut menjadi melebar, tidak hanya dibuat shalat maupun pengajaran Al-Qur'an saja. tetapi juga dibuat kegiatan yang lainnya seperti, pengobatan warga dengan adanya poliklinik, Hadroh (sholawat Banjari), pengajian ibu-ibu dan pengajian bapak-bapak. Dan sampai sekarang ada banyak aktivitas budaya keagamaan yang ada di masjid Al-Ikhlas tersebut.

\section{REFERENSI}

Ayub, Moh. E.. (1996). Manajemen Masjid: Petunjuk Praktis bagi Para Pengurus. Jakarta: Gema Insani.

Gazalba, Sidi. (1989). Mesjid Pusat Ibadat Dan Kebudayaan Islam. Jakarta: Pustaka AlHusna.

Handryant, Aisyah Nur. (2010). Masjid Sebagai Pusat Pengembangan Masyarakat Integrasi Konsep Habluminallah, Habluminannas, Dan Habluminal Alam. Malang: UIN-Maliki Press.

Harahap, Sofyan Syafrib. (1995). Manajemen Masjid. Jakarta: Dana Bakti Prima Jaya.

Hasbullah. (2001). Sejarah Pendidikan Islam di Indonesia. Jakarta: PT. Raja Grafindo Persada.

Kartodirjo, Sartono. (2016). Pendekatan Ilmu Sosial dalam Metodologi Sejarah. Yogyakarta: Ombak.

Kuntowijoyo. (1995). Pengantar Ilmu Sejarah. Yogyakarta: Yayasan Benteng Budaya.

Kurniawan, Samsul. (2014). Masjid dalam Lintasan Sejarah Umat Islam. Jurnal Khatulistiwa: Journal of Islamic Studies, 4(2), September 2014.

Rifa'i, A. Bachrun. (2005). Manajemen Masjid. Bandung: Benang Merah Press.

Tanpa Pengarang, (Tanpa Tahun). Pedoman Manajemen Masjid. Tanpa Kota: Hasil Kerjasama ICMI Orsat Cempaka Putih Fokus Babinrohis Pusat dan Yayasan Kado Anak Muslim.

\section{Wawancara}


Jumirah, Wawancara, Tempel, pada tanggal 7 Maret 2019.

Panjang Sularso, Wawancara, Tempel, pada tanggal 9 Maret 2019.

Supriyadi, Wawancara, Tempel, pada tanggal o5 Maret 2019.

Siti Lestari, Wawancara, Tempel, pada tanggal 1o Maret 2019.

Sukirman, wawancara, Tempel, pada tanggal zo Maret 2019.

Zaenal, Wawancara, Tempel, pada tanggal o6 Maret 2019.

\footnotetext{
1 Supriyadi, wawancara, Tempel, 05 Maret 2019.

2 Tanpa Pengarang, (Tanpa Tahun). Pedoman Manajemen Masjid. Tanpa Kota: Hasil Kerjasama ICMI Orsat Cempaka Putih Fokus Babinrohis Pusat dan Yayasan Kado Anak Muslim, p. 141.

3 Panjang Sularso, wawancara, Tempel, 9 Maret 2019.

${ }^{4}$ Tanpa Pengarang, (Tanpa Tahun). Pedoman Manajemen Masjid. Tanpa Kota: Hasil Kerjasama ICMI Orsat Cempaka Putih Fokus Babinrohis Pusat dan Yayasan Kado Anak Muslim, p. 141.

${ }^{5}$ Siti Lestari, wawancara, Tempel, 10 Maret 2019.

6 Jumirah, wawancara, Tempel, 7 Maret 2019.

7 Tanpa Pengarang, (Tanpa Tahun). Pedoman Manajemen Masjid. Tanpa Kota: Hasil Kerjasama ICMI Orsat Cempaka Putih Fokus Babinrohis Pusat dan Yayasan Kado Anak Muslim, p. 141.

8 Zaenal, wawancara, Tempel, pada tanggal 06 Maret 2019.

9 Samsul Kurniawan, "Masjid Dalam Lintasan Sejarah Umat Islam", p. 169.

${ }^{10}$ Sukirman, wawancara, Tempel, pada tanggal 30 Maret 2019.
} 